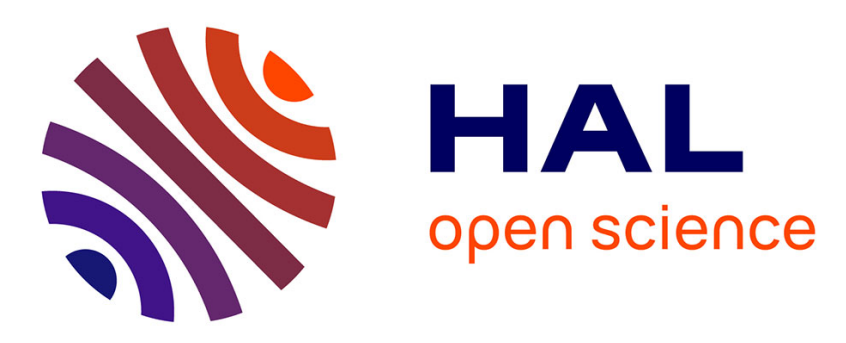

\title{
Aboveground stand-level biomass estimation: a comparison of two methods for major forest species in northwest Spain \\ Castedo-Dorado, Gómez-García, Diéguez-Aranda, Barrio-Anta, Crecente-Campo
}

\section{To cite this version:}

Castedo-Dorado, Gómez-García, Diéguez-Aranda, Barrio-Anta, Crecente-Campo. Aboveground stand-level biomass estimation: a comparison of two methods for major forest species in northwest Spain. Annals of Forest Science, 2012, 69 (6), pp.735-746. 10.1007/s13595-012-0191-6 . hal-00930841

\section{HAL Id: hal-00930841 https://hal.science/hal-00930841}

Submitted on 1 Jan 2012

HAL is a multi-disciplinary open access archive for the deposit and dissemination of scientific research documents, whether they are published or not. The documents may come from teaching and research institutions in France or abroad, or from public or private research centers.
L'archive ouverte pluridisciplinaire HAL, est destinée au dépôt et à la diffusion de documents scientifiques de niveau recherche, publiés ou non, émanant des établissements d'enseignement et de recherche français ou étrangers, des laboratoires publics ou privés. 


\title{
Aboveground stand-level biomass estimation: a comparison of two methods for major forest species in northwest Spain
}

\author{
Fernando Castedo-Dorado • Esteban Gómez-García • \\ Ulises Diéguez-Aranda • Marcos Barrio-Anta • \\ Felipe Crecente-Campo
}

Received: 19 May 2011 / Accepted: 30 January 2012 /Published online: 13 March 2012

(C) INRA / Springer-Verlag France 2012

\begin{abstract}
- Context The scaling-up approach (which requires the use of individual tree biomass equations and data) is one of the most commonly used methods for estimating stand biomass
\end{abstract}

Handling Editor: Matthias Dobbertin

Contribution of the co-authors Fernando Castedo-Dorado and Felipe Crecente-Campo analyzed the data and wrote the manuscript. Esteban Gómez-García, and Marcos Barrio-Anta provided part of the experimental data and the individual-tree biomass equations used and revised the text. Ulises Diéguez-Aranda provided technical assistance in model fitting and supervised the writing of the manuscript.

F. Castedo-Dorado $(\bowtie)$

Departamento de Ingeniería y Ciencias Agrarias, Universidad de León. Escuela Superior y Técnica de Ingeniería Agraria,

Avda. de Astorga s/n,

24400 Ponferrada, León, Spain

e-mail: fcasd@unileon.es

E. Gómez-García • U. Diéguez-Aranda • F. Crecente-Campo

Departamento de Ingeniería Agroforestal,

Universidad de Santiago de Compostela. Escuela Politécnica Superior,

R/ Benigno Ledo, Campus Universitario,

27002 Lugo, Spain

E. Gómez-García

e-mail: esteban.gomez@usc.es

U. Diéguez-Aranda

e-mail: ulises.dieguez@usc.es

F. Crecente-Campo

e-mail: felipe.crecente@usc.es

M. Barrio-Anta

Departamento de Biología de Organismos y Sistemas,

Universidad de Oviedo. Escuela Politécnica de Mieres,

C/Gonzalo Gutiérrez Quirós,

33600 Mieres, Asturias, Spain

e-mail: barriomarcos@uniovi.es at a local scale. However, biomass prediction over large management areas requires more efficient methods.

- Aims Two methods of estimating aboveground stand biomass were developed and compared: stand biomass equations (SBE) including observed stand variables, and SBE including biomass expansion factors (BEF) and stand volume.

- Methods Two types of systems of additive equations were fitted simultaneously for components and total aboveground stand biomass, to ensure additivity. Inherent correlations among biomass components were also taken into account in the fitting process.

- Results The systems explained a high percentage of the observed variability. The SBE systems that included observed stand variables provided more accurate estimates than those that included BEF and stand volume. However, the latter were found to be more precise for stem wood and total aboveground biomass prediction.

- Conclusions Both approaches provide a direct link between forest inventory data, outputs from whole-stand growth models, and biomass estimates at stand level. Taking into account that the inventory effort is similar for both alternatives, the choice of which to use will depend on the data available and on the relative importance of the biomass components for the end-users.

Keywords Aboveground stand biomass - Additivity · Stand variables $\cdot$ Biomass expansion factors $\cdot \mathrm{NW}$ of Spain

\section{Introduction}

The importance of estimating forest biomass and carbon stocks has increased as a result of the Climate Convention and the Kyoto Protocol, which recognize that forest ecosystems may contribute to mitigating the human-induced 
greenhouse effect by extracting and storing excess carbon from the atmosphere. In addition, the need to reduce fossil fuel dependence has resulted in consideration of forest residues (mainly branches and foliage) as a useful renewable source of biomass. To satisfy the requirements of both the Kyoto Protocol and the need to quantify the amount of biomass available for energy purposes, accurate and effective methods of estimating biomass and carbon stocks are increasingly necessary.

Several procedures are used to estimate forest biomass, and the choice of method mainly depends on the data available. The scaling-up approach is one of the most commonly used methods, especially at a local scale. This method involves the development of individual-tree biomass equations and prediction of stand biomass as the sum of predicted biomass of individual trees (e.g., Balboa-Murias et al. 2006). The approach requires biomass equations for individual trees as well as measurement of diameter at breast height and, in some cases, the height of each tree (e.g., Wang et al. 2011).

However, estimation of forest biomass in larger management areas requires more efficient estimation methods, in which stand biomass equations (SBE) or biomass expansion factors (BEF) must be used (Somogyi et al. 2007). SBE estimate total or component biomass (needles, branches, wood, bark, etc.) at stand level from stand variables that are easily obtained from forest inventories or from wholestand models (e.g., Monserud et al. 1996; Bi et al. 2010). On the other hand, BEFs are multipliers that enable expansion of the growing stock (i.e., the stand stem volume of living trees) to account for total or component biomass in a stand (Lehtonen et al. 2004; Wirth et al. 2004; Somogyi et al. 2007). In general, constant BEFs have been applied (e.g., UN-ECE/FAO 2000). Recent methodological guidelines from the IPCC $(2003,2006)$ include sets of speciesspecific default values for BEF, although it is recognized that the average values reported are expected to be highly variable. It is well known that BEF vary depending on growth conditions (e.g., Wirth et al. 2004; Albaugh et al. 2009) and the stage of stand development, expressed by stand age or size (Lehtonen et al. 2004; Levy et al. 2004; Jalkanen et al. 2005), because all of these factors affect the biomass allocation strategies of trees.

Individual-tree biomass equations have been developed for the major forest species in NW Spain (Diéguez-Aranda et al. 2009). However, the data required for application of these equations are not always available. In addition, most of the growth models developed in the region function on a stand-basis, and thus mainly predict stand variables (dominant height, stand basal area, stand density, stand volume, etc.). The use of stand variables avoids the need to disaggregate the stand basal area predicted from whole-stand growth models into diameter classes, for estimation of stand biomass. It also avoids having to deal with complex error propagation procedures that involve model components at different spatial scales in the disaggregation process. Taking these aspects into account, the most efficient approaches for predicting stand biomass in the region are those based on explanatory variables obtained at stand level.

The objectives of the present study were: (1) to develop two alternative systems of additive equations for estimating aboveground biomass of the major forest species in NW Spain (Betula pubescens, Eucalyptus globulus, Pinus pinaster, Pinus radiata, Pinus sylvestris, and Quercus robur) at stand level and (2) to compare the predictive ability of the alternative systems for estimating total and component stand biomass.

\section{Material and methods}

\subsection{Data}

Data from permanent sample plots and from the Spanish National Forest Inventory (SNFI) were used in the study. The permanent sample plots (1,279 plots) were established by the University of Santiago de Compostela and the University of Oviedo in stands of all species studied, except for E. globulus. Some of the initially established plots were remeasured, thus providing a total of 1,738 measurements (on average 1.3 measurements/plot for all species). The plots were located throughout the area of distribution of the species in NW Spain, and were subjectively selected to represent the existing range of ages, stand densities, and sites. The plot size ranged from 400 to $1,200 \mathrm{~m}^{2}$, depending on stand density, to achieve a minimum of 30 trees per plot. Diameter at breast height $(d)$ was measured in each tree, and total tree height $(h)$ was measured in a randomized sample of 30 trees, and in an additional sample of the dominant trees (the proportion of the 100 thickest trees per hectare, depending on plot size). For some species and measurement occasions, total tree height was available for all trees in the plots.

For E. globulus, the data were obtained from the second and third SNFI in Galicia. The SNFI is a systematic sample of permanent, circular nested plots in a $1 \mathrm{~km}$ square grid, in which trees are sampled within different radii according to their diameter at breast height. For each plot and measurement occasion, $d$ and $h$ were recorded for all sampled trees. All plots with more than $90 \%$ eucalyptus stems and with no anomalies (see Crecente-Campo et al. 2010) were selected for the present study (976 plots, 1,225 measurement occasions). Data from the SNFI was not used for the remaining species because sufficient higher-quality data from permanent plots were available.

The overall data consisted of 2,963 plot-based estimates of components as well as total aboveground stand biomass 
derived from tree-level biomass equations. These treebiomass equations were developed with data from destructively sampled trees, including data on aboveground biomass per component. For most species, the following components were considered: leaves/needles, twigs $(0.5 \mathrm{~cm}$ maximum butt diameter), thin branches ( $2 \mathrm{~cm}$ maximum butt diameter and $0.5 \mathrm{~cm}$ minimum top diameter), thick branches (branches with $7 \mathrm{~cm}$ maximum butt diameter and $2 \mathrm{~cm}$ minimum top diameter), stem bark, and stem wood (debarked logs with a thin-end diameter of $7 \mathrm{~cm}$ ). Existing equations for treebiomass estimation were used for $P$. pinaster and $P$. radiata (Balboa-Murias et al. 2006), B. pubescens and Q. robur (Gómez-García 2011), and E. globulus (Diéguez-Aranda et al. 2009, pp. 238-240). The equations were developed on the basis of data from trees sampled for biomass analysis in NW Spain $(50,34,125,48,50$ trees of B. pubescens, E. globulus, $P$. pinaster, $P$. radiata, and $Q$. robur, respectively) and most of them explained more than $85 \%$ of the observed variability in component biomass. Further details of the development of these equations are reported elsewhere (Diéguez-Aranda et al. 2009). For P. sylvestris, individual-tree biomass equations were developed at a national scale with data from 316 trees (Montero et al. 2005). Although in these studies, individualtree equations for belowground biomass are available for $B$. pubescens, P. radiata, $Q$. robur, and $P$. sylvestris, they were based on very small samples of $6,11,12$, and 14 trees, respectively. Therefore, large estimation errors are expected (Chave et al. 2004) and their use for quantifying root biomass at stand level is not recommended. If root biomass is required, root/shoot ratios can be used for general species groups (e.g., Levy et al. 2004).

All the equations include $d$ as predictor, and many of them also include $h$. Generalized $h-d$ equations reported by Diéguez-Aranda et al. (2009, p. 188) were used to estimate $h$ for trees in which this variable was not measured. To obtain stand biomass values, individual-tree biomass equations were applied to each tree within the plot; values were obtained on an area basis $\left(\mathrm{Mg} \mathrm{ha}^{-1}\right)$, considering the surface area of the plots. The values thus obtained were assumed to be the best available ("true") stand biomass estimate.

Stand variables available for each plot included number of trees per hectare $\left(N\right.$, trees $\left.\mathrm{ha}^{-1}\right)$, stand basal area $(G$, $\left.\mathrm{m}^{2} \mathrm{ha}^{-1}\right)$, quadratic mean diameter $\left(d_{g}, \mathrm{~cm}\right)$ dominant height $\left(H_{0}, \mathrm{~m}\right)$, and dominant diameter $\left(D_{0}, \mathrm{~cm}\right)$ (defined as the mean height and mean diameter of the 100 largest diameter trees per hectare, respectively), and stand volume $\left(V, \mathrm{~m}^{3}\right)$. The latter variable was calculated by adding the volume of the live trees in each plot estimated with the individual-tree volume equations reported by Diéguez-Aranda et al. (2009, p. 208), which depend on $d$ and $h$. Stand age was not considered as a stand variable for the analysis because: (1) it was not available for E. globulus plots, as it is not measured in the SNFI; (2) a representative stand age it is not easy to obtain in natural stands of $B$. pubescens and Q. robur, and (3) its absence makes application of the models easier because it is not usually measured in forest inventories.

The number of plots used for stand biomass estimations, the stand biomass components considered, and the basic description of the stand biomass components data for each species are summarized in Table 1 . The values of total aboveground stand biomass plotted against the stand level variables $G, H_{0}, N$, and $V$ are shown in Fig. 1. According to these values, the data cover the entire duration of stand development for all the species and for the rotations usually applied in NW Spain.

\subsection{Methodology}

Two alternative approaches for stand biomass estimation were proposed: (1) systems of equations in which component and total stand biomass depend on observed stand variables and (2) systems of equations that use stand volume data and appropriate BEF to expand volume estimates to biomass estimates. In both cases, species-specific systems of equations with cross-equation constraints on the structural parameters and cross-equation error correlation were defined for predicting component and total aboveground stand biomass with additivity (Parresol 2001; Bi et al. 2010).

\subsubsection{SBE including observed stand variables}

In this approach, each system of equations has the following general formulation:

$$
\begin{aligned}
W_{i} & =a_{i 0} X_{j}^{a_{i j}}+\varepsilon_{i} \\
W_{T} & =\sum_{i=1}^{n} W_{i}+\varepsilon_{T}
\end{aligned}
$$

where, $W_{i}$ represents the stand biomass for the $i$ th component, $W_{T}$ is the total aboveground stand biomass (i.e., the sum of all the stand biomass components), $X_{j}$ are stand variables $(j=1, \ldots, m), a_{i 0}-a_{i j}$ are parameters to be estimated in the fitting process, and $\varepsilon_{i}, \varepsilon_{T}$ are intercorrelated error terms. The allometric functions adopted in the formulation of the systems of equations were selected because they are the most frequently used for describing the allometric relationships between tree/stand biomass and tree/stand variables (e.g., Bi et al. 2010; Shaiek et al. 2011).

The stand biomass components considered depend on the individual-tree biomass component equations available for each species and vary in number between five and six (see Table 1). A stepwise regression procedure was used to select the $j$ th regressor stand variables for each $i$ th biomass component equation, over the linearized version of the models taking natural logarithms. The significance level for entering 
Table 1 Number of plots and measurements used for biomass estimations, and summary statistics of the biomass components considered for each species

\begin{tabular}{|c|c|c|c|c|c|c|c|c|c|c|c|}
\hline \multirow[t]{2}{*}{ Species } & & \multicolumn{10}{|c|}{ Biomass components } \\
\hline & & $W_{w+b 7}$ & $W_{b}$ & $W_{w+b}$ & $W_{b 7}$ & $W_{b 2-7}$ & $W_{b 0.5-7}$ & $W_{b 0.5-2}$ & $W_{b 0-0.5}$ & $W_{b 0-2}$ & $W_{l}$ \\
\hline \multirow{4}{*}{$\begin{array}{l}\text { B. pubescens (149 plots, } \\
189 \text { measurements) }\end{array}$} & Mean & 74.19 & 12.45 & & & 24.16 & & 13.48 & 5.911 & & 4.750 \\
\hline & Max & 236.8 & 38.11 & & & 58.52 & & 34.20 & 13.82 & & 14.53 \\
\hline & Min & 2.395 & 1.022 & & & 4.475 & & 2.033 & 1.265 & & 0.4379 \\
\hline & SD & 42.81 & 6.931 & & & 9.748 & & 5.903 & 2.270 & & 2.557 \\
\hline \multirow{4}{*}{$\begin{array}{l}\text { E. globulus (976 plots, } \\
1,225 \text { measurements) }\end{array}$} & Mean & 72.69 & 9.741 & & & & 6.033 & & 1.171 & & 5.117 \\
\hline & Max & 529.9 & 56.64 & & & & 37.75 & & 5.020 & & 23.68 \\
\hline & Min & 4.172 & 0.7439 & & & & 0.4086 & & 0.1447 & & 0.5605 \\
\hline & S.D. & 64.30 & 7.349 & & & & 4.828 & & 0.6967 & & 3.219 \\
\hline \multirow{4}{*}{$\begin{array}{l}\text { P. pinaster (600 plots, } \\
600 \text { measurements) }\end{array}$} & Mean & 58.24 & 13.65 & & & 6.826 & & 8.881 & 1.197 & & 6.339 \\
\hline & Max & 286.8 & 49.78 & & & 50.33 & & 20.27 & 3.216 & & 19.88 \\
\hline & Min & 3.817 & 1.151 & & & 1.018 & & 2.886 & 0.1607 & & 0.6418 \\
\hline & SD & 41.76 & 7.811 & & & 6.923 & & 2.707 & 0.5403 & & 3.303 \\
\hline \multirow{4}{*}{$\begin{array}{l}\text { P. radiata ( } 220 \text { plots, } \\
460 \text { measurements })\end{array}$} & Mean & 104.2 & 14.53 & & & 11.55 & & 7.476 & 3.070 & & 7.439 \\
\hline & Max & 362.6 & 47.80 & & & 36.03 & & 17.39 & 7.472 & & 16.07 \\
\hline & Min & 4.872 & 1.108 & & & 2.166 & & 1.646 & 0.4709 & & 1.454 \\
\hline & SD & 56.33 & 7.141 & & & 4.841 & & 2.258 & 0.9344 & & 1.943 \\
\hline \multirow{4}{*}{$\begin{array}{l}\text { P. sylvestris (162 plots, } \\
234 \text { measurements) }\end{array}$} & Mean & & & 96.06 & 1.217 & 14.81 & & & & 15.64 & 11.81 \\
\hline & Max & & & 243.9 & 5.619 & 30.65 & & & & 27.02 & 20.39 \\
\hline & Min & & & 12.79 & 0.0220 & 3.038 & & & & 4.765 & 3.597 \\
\hline & SD & & & 47.07 & 1.101 & 5.808 & & & & 4.696 & 3.545 \\
\hline \multirow{4}{*}{$\begin{array}{l}\text { Q. robur (148 plots, } \\
255 \text { measurements) }\end{array}$} & Mean & 74.19 & 12.45 & & & 24.16 & & 13.48 & 5.912 & & 4.750 \\
\hline & Max & 236.8 & 38.11 & & & 58.52 & & 34.20 & 13.82 & & 14.53 \\
\hline & Min & 2.395 & 1.022 & & & 4.475 & & 2.033 & 1.265 & & 0.4379 \\
\hline & SD & 42.81 & 6.931 & & & 9.748 & & 5.904 & 2.270 & & 2.557 \\
\hline
\end{tabular}

$W_{w+b 7}=$ wood biomass of stems plus branches with $7 \mathrm{~cm}$ minimum top diameter $\left(\mathrm{Mg} \mathrm{ha}^{-1}\right), W_{w+b}=$ wood plus stem bark biomass $\left(\mathrm{Mg}^{-1}\right), W_{b}=$ stem bark biomass $\left(\mathrm{Mg} \mathrm{ha}^{-1}\right), W_{b 7}=$ wood plus bark biomass of branches with $7 \mathrm{~cm}$ minimum top diameter $\left(\mathrm{Mg} \mathrm{ha}^{-1}\right), W_{b 2-7}=$ wood plus bark biomass of branches with $7 \mathrm{~cm}$ maximum butt diameter and $2 \mathrm{~cm}$ minimum top diameter $\left(\mathrm{Mg} \mathrm{ha}^{-1}\right), W_{b 0.5-7}=$ wood plus bark biomass of branches with $7 \mathrm{~cm}$ maximum butt diameter and $0.5 \mathrm{~cm}$ minimum top diameter $\left(\mathrm{Mg} \mathrm{ha}^{-1}\right), W_{b 0.5-2}=$ wood plus bark biomass of branches with $2 \mathrm{~cm}$ maximum butt diameter and $0.5 \mathrm{~cm}$ minimum top diameter $\left(\mathrm{Mg} \mathrm{ha}^{-1}\right), W_{b 0-2}=$ wood and bark biomass of branches with $2 \mathrm{~cm}$ maximum butt diameter $\left(\mathrm{Mg} \mathrm{ha}^{-1}\right), W_{b 0-0.5}=$ wood and bark biomass of branches with $0.5 \mathrm{~cm}$ maximum butt diameter $\left(\mathrm{Mg} \mathrm{ha}^{-1}\right), W_{l}=$ leaves $/$ needles biomass $\left(\mathrm{Mg} \mathrm{ha}^{-1}\right)$

and maintaining variables in the model was restricted to 0.01 .

The system of equations was fitted using the generalized method of moments (GMM) in the PROC MODEL procedure of SAS/ETS ${ }^{\circledR}$ (SAS Institute Inc. 2008). This method produces efficient parameter estimates under heteroscedastic conditions, without specifying the nature of the heteroscedasticity (Greene 1999; SAS Institute Inc. 2008), and thus avoids estimating the heteroscedastic error variance. The major drawback of this method is that bounds on the predictions cannot be generated without specifying or estimating the error structure (Parresol 2001).

One problem encountered in estimating the system of Eq. 1 was that the error term of the equations for total aboveground stand biomass is a linear combination of the error terms of the biomass component equations, which led to a singular across equation variance-covariance matrix. SAS overcomes this problem by computing a generalized inverse of the variance-covariance matrix, by setting part of the matrix for total stand biomass to zero (SAS Institute Inc. 2008). Although this procedure avoids the problem of singularity by ignoring the correlations between the error term for the total biomass and the error terms for other biomass components, the cross-equation constraints on the structural parameters are still applied in the parameter estimation (Bi et al. 2004, 2010). The parameters estimated from fitting the biomass component equations simultaneously, without considering the equation for total stand biomass, are therefore not equal. 

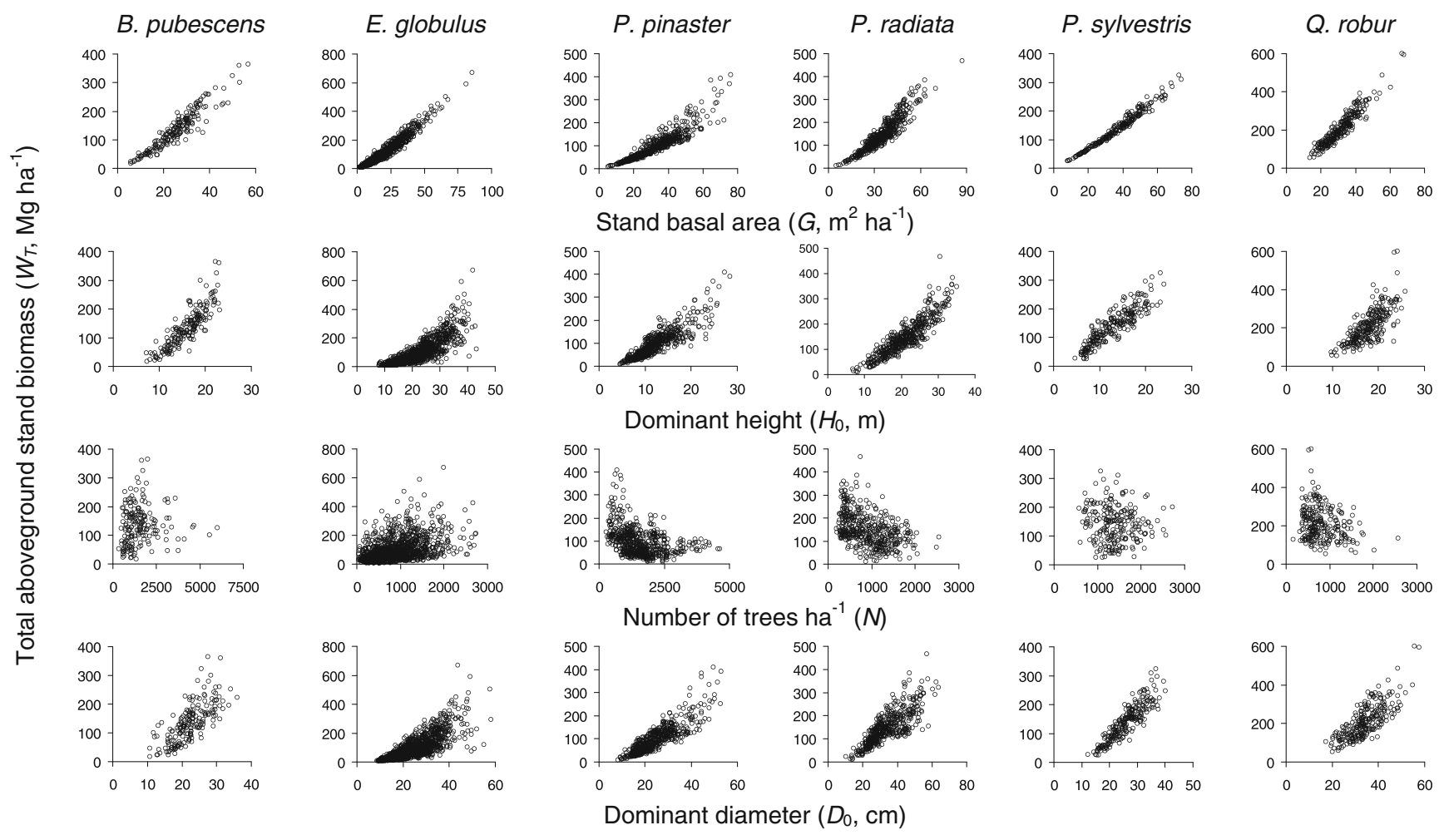

Fig. 1 Plots of total aboveground biomass versus stand level variables for the six species analyzed
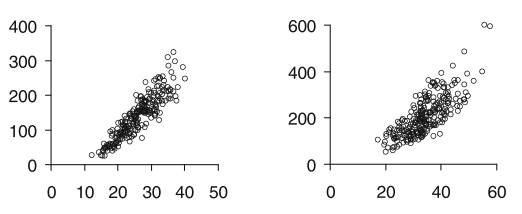

\subsubsection{SBE including BEF and stand volume}

The following definition of stand-level BEF was used in this study:

$$
\mathrm{BEF}_{i}=\frac{W_{i}}{V}
$$

where, $\mathrm{BEF}_{i}$ is the biomass expansion factor $\left(\mathrm{Mg} \mathrm{m}^{-3}\right)$ for the $i$ th biomass component, $W_{i}$ is the dry weight of the stand biomass component $\left(\mathrm{Mg} \mathrm{ha}^{-1}\right)$, and $V$ is the total stand volume $\left(\mathrm{m}^{3} \mathrm{ha}^{-1}\right)$.

Stand-level $\mathrm{BEF}_{i}$ were computed for each plot and species, considering $W_{i}$ as the sum of the estimated tree-level biomass of $i$ th component over trees measured on the sample plot, and $V$ as the corresponding sum of tree-level stem volumes. Scatter plots of species-specific stand-level $\mathrm{BEF}_{i}$ against stand variables were examined in order to detect any trends in these relationships, and therefore to decide if standdependent $\mathrm{BEF}_{i}$ models are required. In that case, growing stock and stand age were disregarded as regressor variables. The former was not considered because it is an estimated variable (not actually measured) and therefore has an associated prediction error; the latter was discounted for the reasons explained in the above section.

Taking into account these considerations and Eq. 2, the following species-specific system of equations was defined:

$$
\begin{aligned}
W_{i} & =V \mathrm{BEF}_{i}\left(X_{j}\right)+\varepsilon_{i} \\
W_{T} & =\sum_{i=1}^{n} W_{i}+\varepsilon_{T}
\end{aligned}
$$

where, $\mathrm{BEF}_{i}\left(X_{j}\right)$ are stand-dependent functions for predicting $\mathrm{BEF}_{i}$.

Seemingly unrelated regression (SUR) available in the SAS/ETS ${ }^{\circledR}$ PROC MODEL procedure (SAS Institute Inc. 2008) was used for model fitting. This regression method was selected because the relationships between stand biomass components and stand volume were quite homoscedastic. Under homocedastic conditions, even under the constraint of additivity, the SUR estimator produces lower variance and is more efficient than other estimation methods (Parresol 1999; Bi et al. 2001).

\subsubsection{Model evaluation}

Measurement of the goodness-of-fit for the models was carried out by use of the root mean squared error (RMSE) and the coefficient of determination $\left(R^{2}\right)$. The RMSE provides a measure of the precision of the estimates in the same units as the dependent variable and the coefficient of determination measures the amount of the observed variability explained by the model.

The possible existence of bias for both types of SBE was evaluated by the use of $F$ test. This test checks the null 
hypothesis that the slope of the linear models fitted to the scatter plots of observed against estimated values was equal to 1 , at the same time as the intercept was equal to 0 .

A validation dataset was not used to evaluate the accuracy of the final models in stand biomass and BEF predictions. The only method that can be regarded as "true" validation involves the use of a new independent dataset (Vanclay and Skovsgaard 1997; Yang et al. 2004), although alternative approaches are used because of the scarcity of such data. The common method of splitting the dataset in two portions does not provide additional information and is not recommended from the viewpoint of parameter estimation (Myers 1990). Moreover, other techniques such as double crossvalidation and statistical tests provide very limited information about the predictive ability of the models (Kozak and Kozak 2003; Yang et. al. 2004).

\section{Results}

The parameter estimates and the goodness-of-fit statistics of the SBE including observed stand variables are shown in Table 2. All parameter estimates were significant at $P<0.01$. All the equations performed well and generally explained between $85 \%$ and $99 \%$ of the observed stand biomass variability for all the species (for only two of these components, the variability explained was lower than $85 \%$ : needle biomass for $P$. radiata and twigs biomass for $Q$. robur). As expected, the coefficients of determination were generally highest for stem wood biomass and lowest for stand foliage and thin branch biomass components. Examination of the residuals revealed that all the regression models were unbiased with respect to the independent variables for the data range used.

The biomass expansion factors for leaves/needles $\left(\mathrm{BEF}_{l}\right)$, branches $\left(\mathrm{BEF}_{\text {branches }}\right)$, and total aboveground biomass $\left(\mathrm{BEF}_{T}\right)$ were plotted against the most closely related stand variables (Fig. 2). The constant values for $\mathrm{BEF}_{l}, \mathrm{BEF}_{\text {branches, }}$ and $\mathrm{BEF}_{T}$ reported for the whole country (Sabaté et al. 2005) are also shown. The large variation in $\mathrm{BEF}_{i}$ for all species explains why these factors were considered as standdependent. The following nonlinear function was found to be the most adequate for modeling the relationship between $\mathrm{BEF}_{i}$ and stand variables:

$\operatorname{BEF}_{i}\left(X_{j}\right)=X_{j}\left(b_{0 i}+b_{1 i} X_{j}\right)$

where, $b_{0 i}$ and $b_{1 i}$ are model parameters, and $X_{j}$ are stand variables.

The SBE developed from stand-dependent BEF and stand volume are shown in Table 3. All parameter estimates were significant at $P<0.01$. Depending on the species and the biomass component considered, quadratic mean diameter and dominant height were the variables that best explained the biomass expansion factors. For most species and biomass components, the percentage of variability explained by these systems of equations was comparable to that explained by the systems of equations including observed stand variables (Table 2), except for wood biomass and total biomass equations, for which the percentage of variability explained was higher.

A comparison between the two approaches in terms of prediction accuracy in biomass estimation is shown in Table 4. The simultaneous $F$ test shows that, for most biomass components, more biased estimates are expected from the traditional biomass-dependent $\mathrm{BEF}_{i}$ equations than when using SBE including observed stand variables.

However, in terms of precision, the results are not very conclusive. The RMSE was comparable (or even smaller) for the SBE including observed variables. Nevertheless, for the stem wood and total biomass equations, the RMSE was substantially lower for SBE including stand volume and BEF.

\section{Discussion}

As regards the systems of equations including observed stand variables, stand basal area was selected as a predictor for all species and biomass components. This supports previous findings that stand basal area is the most important variable when predicting stand biomass of all components (e.g., Snowdon 1992; Husch et al. 2003; Bi et al. 2010). The estimated parameters related to this variable were in all cases positive numbers, showing that stand biomass increases with basal area.

Nevertheless, for a given stand basal area, there is a large variation in the component and total biomass values (see Fig. 1). Therefore, the use of a second independent variable was generally necessary in order to improve the predictive ability of most of the biomass component equations. Dominant height was the second most important stand variable for most species, and was always significant (except for P. sylvestris) for stem wood and thick branch biomass component equations. Both stand basal area and dominant height have been widely used by foresters to predict volume yield (e.g., Brooks and Wiant 2004), which is closely related to stem wood biomass. Other variables such as dominant diameter and stand density are included in some component equations (especially leaves/needles and branches), and take into account the stage of stand development and the level of competition within the stand. Bi et al. (2010) also found stand density to be a significant variable for branch component equations in radiata pine stands, probably because of the level of competition, which affects branching characteristics and biomass partitioning among components (e.g., Madgwick and Oliver 1985). 
Table 2 SBE including observed variables and goodness-of-fit statistics for the biomass components considered

\begin{tabular}{|c|c|c|c|}
\hline $\begin{array}{l}\text { Stand biomass component } \\
\text { equation }\end{array}$ & $\begin{array}{l}\text { Goodness-of-fit } \\
\text { statistics }\end{array}$ & $\begin{array}{l}\text { Stand biomass component } \\
\text { equation }\end{array}$ & $\begin{array}{l}\text { Goodness-of-fit } \\
\text { statistics }\end{array}$ \\
\hline \multicolumn{2}{|l|}{ B. pubescens } & \multicolumn{2}{|l|}{ E. globulus } \\
\hline$W_{w+b 7}=0.09382 G^{0.8846} H_{0}^{1.3458}$ & $\begin{array}{l}\mathrm{RMSE}=10.4 \\
R^{2}=0.9411\end{array}$ & $W_{w+b 7}=0.1780 G^{0.9417} H_{0}^{1.030}$ & $\begin{array}{l}\mathrm{RMSE}=8.082 \\
R^{2}=0.9842\end{array}$ \\
\hline$W_{b}=0.03712 G^{0.9818} H_{0}^{0.9288}$ & $\begin{array}{l}\mathrm{RMSE}=2.014 \\
R^{2}=0.9157\end{array}$ & $W_{b}=0.1114 G^{0.9147} D_{0}^{0.5589}$ & $\begin{array}{l}\mathrm{RMSE}=0.6788 \\
R^{2}=0.9915\end{array}$ \\
\hline$W_{b 2-7}=0.2443 G^{0.8626} D_{0}^{0.5762}$ & $\begin{array}{l}\mathrm{RMSE}=2.904 \\
R^{2}=0.9115\end{array}$ & \multirow[t]{2}{*}{$W_{b 0.5-7}=1.195 G^{1.396} N^{-0.3664}$} & $\begin{array}{l}\mathrm{RMSE}=0.5986 \\
R^{2}=0.9846\end{array}$ \\
\hline$W_{b 0.5-2}=0.02706 G^{0.7656} D_{0}^{1.191}$ & $\begin{array}{l}\mathrm{RMSE}=2.116 \\
R^{2}=0.8719\end{array}$ & & \\
\hline$W_{b 0-0.5}=0.2557 G^{0.9693}$ & $\begin{array}{l}\mathrm{RMSE}=0.6209 \\
R^{2}=0.9252\end{array}$ & $W_{b 0-0.5}=0.1230 G^{0.6392} N^{0.07186}$ & $\begin{array}{l}\mathrm{RMSE}=0.1847 \\
R^{2}=0.9297\end{array}$ \\
\hline$W_{l}=0.03495 G^{1.176} H_{0}^{0.3813}$ & $\begin{array}{l}\mathrm{RMSE}=0.8100 \\
R^{2}=0.8999\end{array}$ & $W_{l}=0.3065 G^{0.9497} N^{0.01382}$ & $\begin{array}{l}\mathrm{RMSE}=0.2417 \\
R^{2}=0.9944\end{array}$ \\
\hline$W_{T}=\sum W_{i}$ & $\begin{array}{l}\mathrm{RMSE}=16.41 \\
R^{2}=0.9465\end{array}$ & $W_{T}=\sum W_{i}$ & $\begin{array}{l}\mathrm{RMSE}=8.664 \\
R^{2}=0.9883\end{array}$ \\
\hline \multicolumn{2}{|l|}{$P$. pinaster } & \multicolumn{2}{|l|}{ P. radiata } \\
\hline$W_{w+b 7}=0.1406 G^{0.9704} H_{0}^{1.027}$ & $\begin{array}{l}\mathrm{RMSE}=2.466 \\
R^{2}=0.9965\end{array}$ & $W_{w+b 7}=0.09179 G^{0.8535} H_{0}^{1.287}$ & $\begin{array}{l}\mathrm{RMSE}=6.466 \\
R^{2}=0.9868\end{array}$ \\
\hline$W_{b}=0.1379 G^{1.315} H_{0}^{0.0006220}$ & $\begin{array}{l}\mathrm{RMSE}=2.213 \\
R^{2}=0.9198\end{array}$ & $W_{b}=0.2243 G^{1.420} N^{-0.1358}$ & $\begin{array}{l}\mathrm{RMSE}=1.491 \\
R^{2}=0.9564\end{array}$ \\
\hline$W_{b 2-7}=0.003595 G^{0.7656} H_{0}^{1.862}$ & $\begin{array}{l}\mathrm{RMSE}=1.295 \\
R^{2}=0.9651\end{array}$ & $W_{b 2-7}=0.05769 G^{0.8482} H_{0}^{0.7364}$ & $\begin{array}{l}\mathrm{RMSE}=0.9095 \\
R^{2}=0.9648\end{array}$ \\
\hline$W_{b 0.5-2}=1.318 G^{0.8573} H_{0}^{-0.4197}$ & $\begin{array}{l}\mathrm{RMSE}=0.7904 \\
R^{2}=0.9148\end{array}$ & $W_{b 0.5-2}=0.4686 G^{1.115} H_{0}^{-0.3868}$ & $\begin{array}{l}\mathrm{RMSE}=0.8784 \\
R^{2}=0.8488\end{array}$ \\
\hline$W_{b 0-0.5}=0.02330 G^{1.128}$ & $\begin{array}{l}\mathrm{RMSE}=0.0635 \\
R^{2}=0.9862\end{array}$ & $W_{b 0-0.5}=0.09996 G^{0.9642} N^{-0.00104}$ & $\begin{array}{l}\mathrm{RMSE}=0.0382 \\
R^{2}=0.9983\end{array}$ \\
\hline$W_{l}=1.685 G^{1.159} N^{-0.3755}$ & $\begin{array}{l}\mathrm{RMSE}=0.8092 \\
R^{2}=0.9400\end{array}$ & $W_{l}=0.01039 G^{1.032} N^{0.4380}$ & $\begin{array}{l}\mathrm{RMSE}=1.350 \\
R^{2}=0.5178\end{array}$ \\
\hline$W_{T}=\sum W_{i}$ & $\begin{array}{l}\mathrm{RMSE}=3.613 \\
R^{2}=0.9966\end{array}$ & $W_{T}=\sum W_{i}$ & $\begin{array}{l}\mathrm{RMSE}=4.435 \\
R^{2}=0.9962\end{array}$ \\
\hline \multicolumn{2}{|l|}{ P. sylvestris } & \multicolumn{2}{|l|}{ Q. robur } \\
\hline$W_{w+b}=7.691 G^{1.346} N^{-0.3301}$ & $\begin{array}{l}\mathrm{RMSE}=1.708 \\
R^{2}=0.9987\end{array}$ & $W_{w+b 7}=0.1534 G^{1.078} H_{0}^{1.017}$ & $\begin{array}{l}\mathrm{RMSE}=10.49 \\
R^{2}=0.9656\end{array}$ \\
\hline$W_{b 7}=2.041 \cdot 10^{-7} G^{0.3580} D_{0}^{4.275}$ & $\begin{array}{l}\mathrm{RMSE}=0.3237 \\
R^{2}=0.9138\end{array}$ & $W_{b}=0.02851 G^{1.065} H_{0}^{0.9601}$ & $\begin{array}{l}\mathrm{RMSE}=1.489 \\
R^{2}=0.9673\end{array}$ \\
\hline$W_{b 2-7}=0.3202 G^{0.9897} H_{0}^{0.09715}$ & $\begin{array}{l}\mathrm{RMSE}=0.2588 \\
R^{2}=0.9980\end{array}$ & $W_{b 2-7}=0.07689 G^{1.064} H_{0}^{0.9634}$ & $\begin{array}{l}\mathrm{RMSE}=4.036 \\
R^{2}=0.9674\end{array}$ \\
\hline$W_{b 0-2}=0.1803 G^{0.7567} N^{0.2407}$ & $\begin{array}{l}\mathrm{RMSE}=0.1151 \\
R^{2}=0.9994\end{array}$ & $W_{b 0.5-2}=0.4668 G^{0.7987}$ & $\begin{array}{l}\mathrm{RMSE}=0.6912 \\
R^{2}=0.8573\end{array}$ \\
\hline & & $W_{b 0-0.5}=0.3582 G^{0.6136}$ & $\begin{array}{l}\mathrm{RMSE}=0.4220 \\
R^{2}=0.6213\end{array}$ \\
\hline$W_{l}=0.1340 G^{0.7575} N^{0.2424}$ & $\begin{array}{l}\mathrm{RMSE}=0.0898 \\
R^{2}=0.9994\end{array}$ & $W_{l}=0.04077 G^{1.416}$ & $\begin{array}{l}\mathrm{RMSE}=0.8134 \\
R^{2}=0.8927\end{array}$ \\
\hline$W_{T}=\sum W_{i}$ & $\begin{array}{l}\mathrm{RMSE}=1.673 \\
R^{2}=0.9993\end{array}$ & $W_{T}=\sum W_{i}$ & $\begin{array}{l}\mathrm{RMSE}=16.84 \\
R^{2}=0.9668\end{array}$ \\
\hline
\end{tabular}

performed adequately for the observed data range. Other authors (e.g., Bi et al. 2010) included transformations of
See Table 1 for an explanation of the biomass components and stand variables. RMSE values in $\mathrm{Mg} \mathrm{ha}^{-1}$ components are not biologically realistic, the equations 

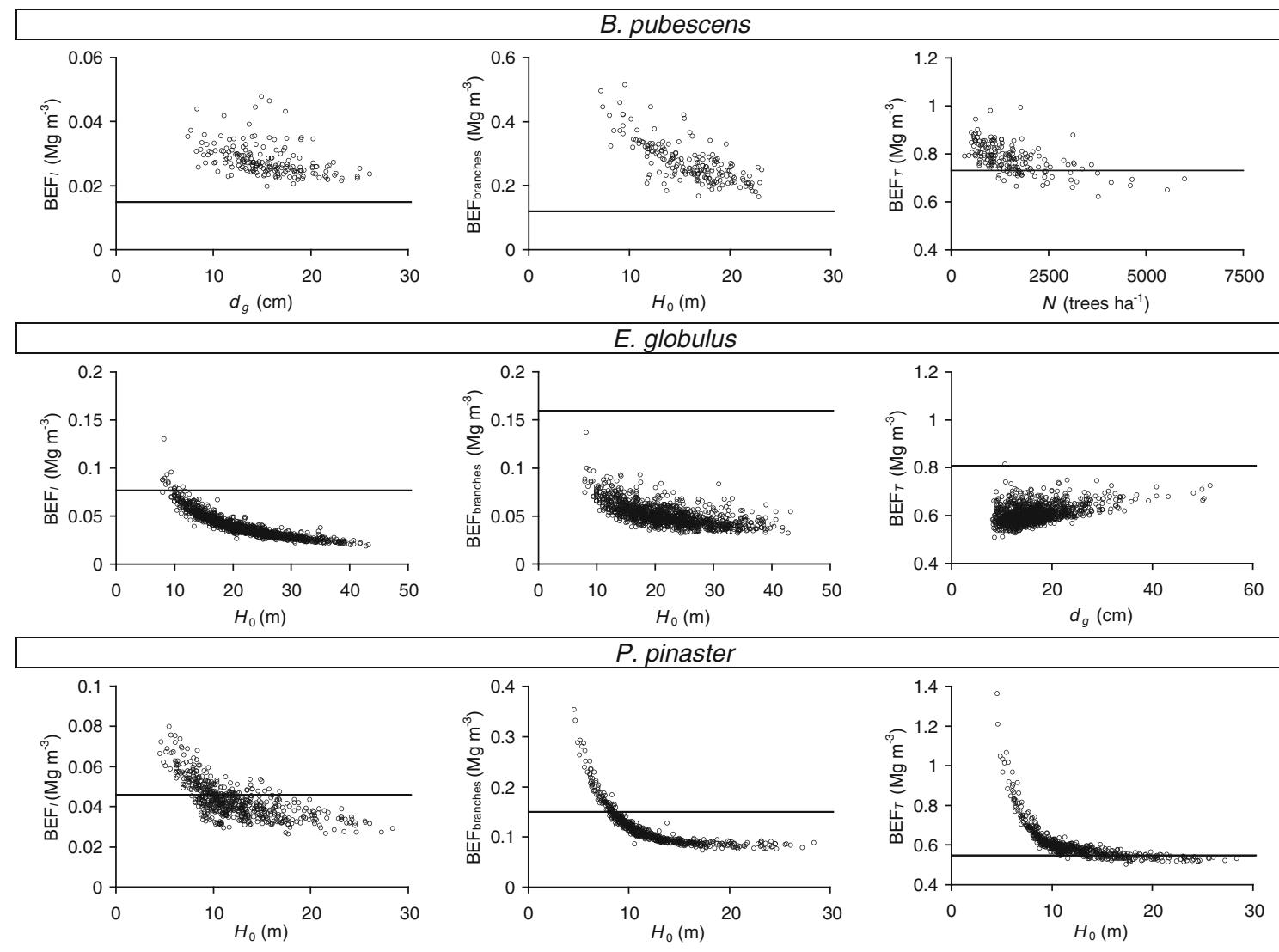

P. pinaster
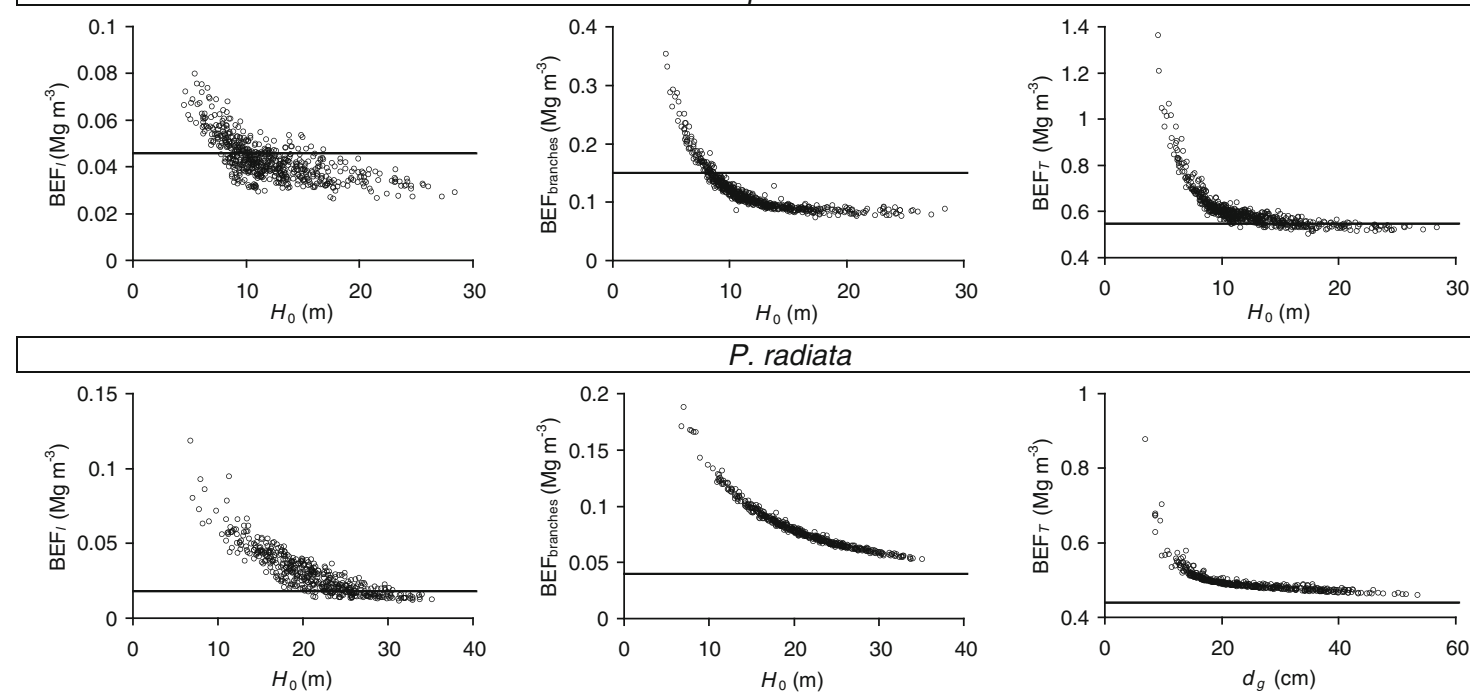

\section{P. radiata}
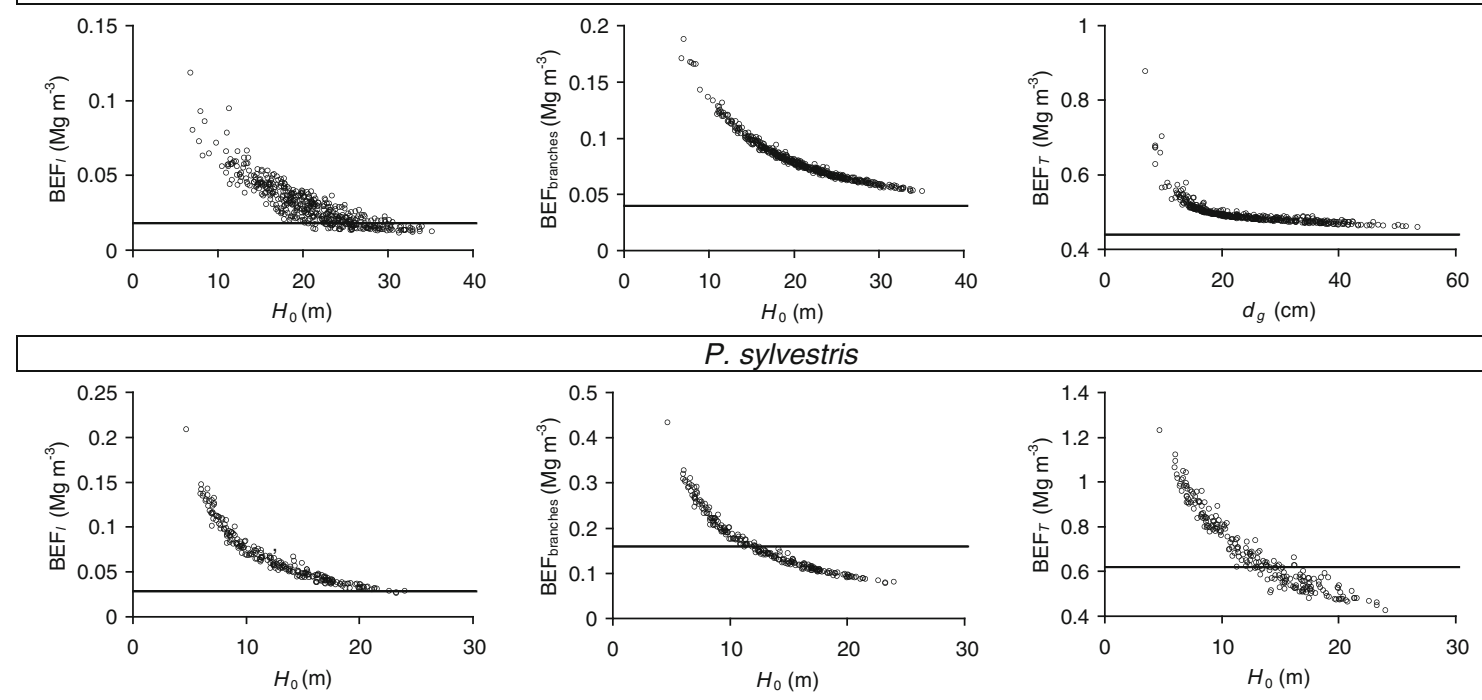

P. sylvestris
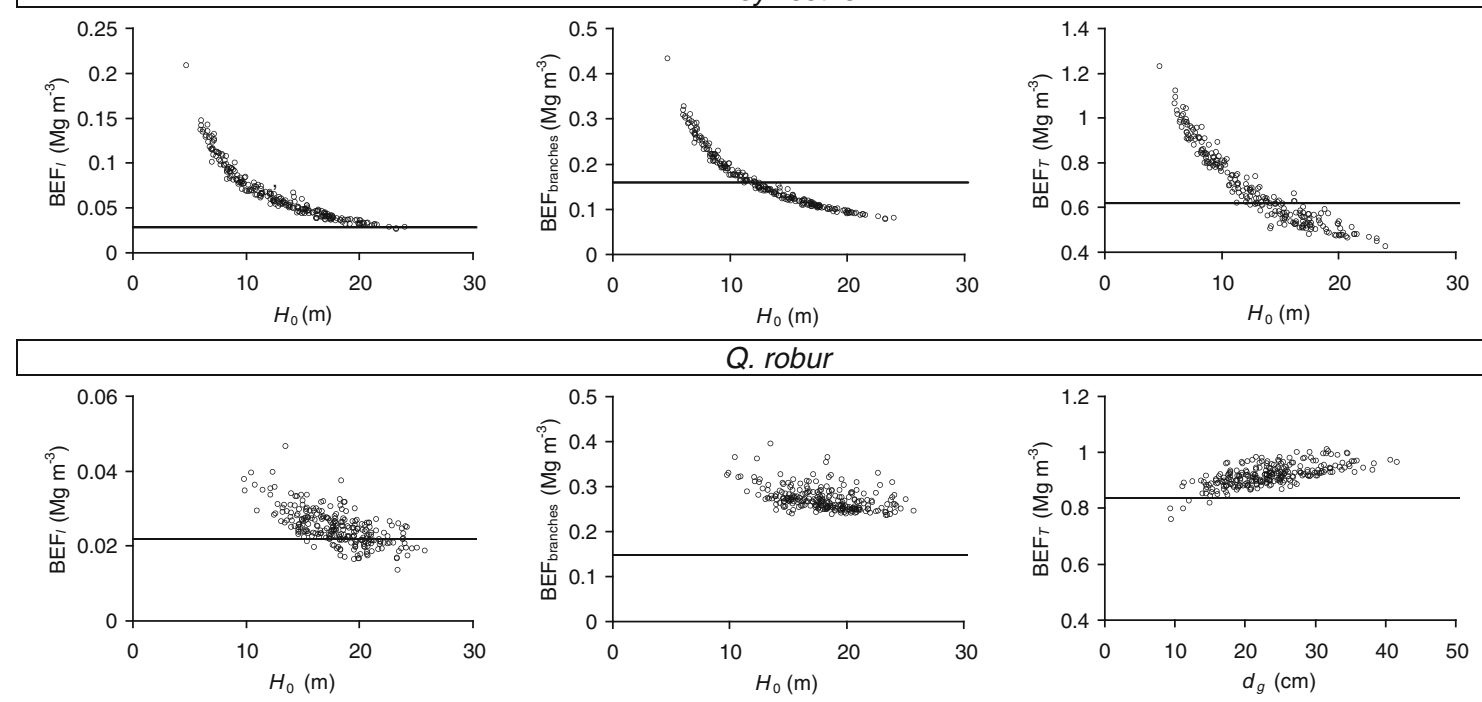

Q. robur
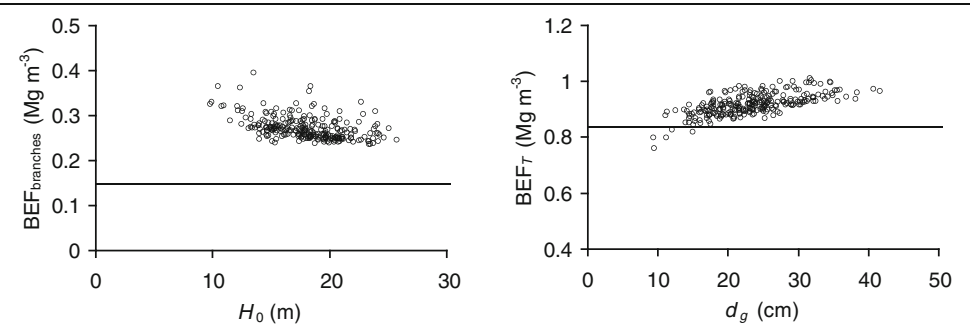

Fig. 2 Plots of biomass expansion factors for needles/leaves $\left(\mathrm{BEF}_{l}\right)$, branches $\left(\mathrm{BEF}_{\text {branches }}\right)$, and total aboveground biomass $\left(\mathrm{BEF}_{T}\right)$ versus the most closely related stand variables. The horizontal line represents the constant $\mathrm{BEF}_{i}$ reported for the species in Spain (Sabaté et al. 2005) 
Table 3 SBE including stand-dependent BEF and stand volume and goodness of fit statistics for the biomass components considered

\begin{tabular}{|c|c|c|c|}
\hline Stand biomass component equation & Goodness-of-fit statistics & Stand biomass component equation & Goodness-of-fit statistics \\
\hline B. pubescens & & E. globulus & \\
\hline$W_{w+b 7}=\left(d_{g} /\left(11.08+1.668 d_{g}\right)\right) V$ & $\begin{array}{l}\mathrm{RMSE}=1.975 \\
R^{2}=0.9979\end{array}$ & $W_{w+b 7}=\left(d_{g} /\left(7.330+1.739 d_{g}\right)\right) V$ & $\begin{array}{l}\mathrm{RMSE}=2.055 \\
R^{2}=0.9990\end{array}$ \\
\hline$W_{b}=\left(d_{g} /\left(77.45+9.399 d_{g}\right)\right) V$ & $\begin{array}{l}\mathrm{RMSE}=0.7345 \\
R^{2}=0.9888\end{array}$ & $W_{b}=\left(H_{0} /\left(-113.0+21.02 H_{0}\right)\right) V$ & $\begin{array}{l}\mathrm{RMSE}=1.570 \\
R^{2}=0.9543\end{array}$ \\
\hline$W_{b 2-7}=\left(H_{0} /\left(-64.52+11.34 H_{0}\right)\right) V$ & $\begin{array}{l}\mathrm{RMSE}=2.031 \\
R^{2}=0.9566\end{array}$ & $W_{0.5-7}=\left(H_{0} /\left(-141.7+31.98 H_{0}\right)\right) V$ & $\begin{array}{l}\mathrm{RMSE}=1.218 \\
R^{2}=0.9364\end{array}$ \\
\hline$W_{b 0.5-2}=\left(H_{0} /\left(-102.7+19.39 H_{0}\right)\right) V$ & $\begin{array}{l}\mathrm{RMSE}=1.347 \\
R^{2}=0.9479\end{array}$ & & \\
\hline$W_{b 0-0.5}=\left(H_{0} /\left(-278.9+47.56 H_{0}\right)\right) V$ & $\begin{array}{l}\mathrm{RMSE}=0.5694 \\
R^{2}=0.9371\end{array}$ & $W_{b 0-0.5}=\left(H_{0} /\left(-1510+207.8 H_{0}\right)\right) V$ & $\begin{array}{l}\mathrm{RMSE}=0.2257 \\
R^{2}=0.8951\end{array}$ \\
\hline$W_{l}=\left(d_{g} /\left(114.1+30.08 d_{g}\right)\right) V$ & $\begin{array}{l}\mathrm{RMSE}=0.1492 \\
R^{2}=0.9966\end{array}$ & $W_{l}=\left(H_{0} /\left(-320.7+45.88 H_{0}\right)\right) V$ & $\begin{array}{l}\mathrm{RMSE}=0.7642 \\
R^{2}=0.9437\end{array}$ \\
\hline$W_{T}=\sum W_{i}$ & $\begin{array}{l}\mathrm{RMSE}=5.916 \\
R^{2}=0.9930\end{array}$ & $W_{T}=\sum W_{i}$ & $\begin{array}{l}\mathrm{RMSE}=4.402 \\
R^{2}=0.9970\end{array}$ \\
\hline P. pinaster & & P. radiata & \\
\hline$W_{w+b 7}=\left(H_{0} /\left(-0.6050+2.893 H_{0}\right)\right) V$ & $\begin{array}{l}\mathrm{RMSE}=1.287 \\
R^{2}=0.9991\end{array}$ & $W_{w+b 7}=\left(H_{0} /\left(8.017+2.568 H_{0}\right)\right) V$ & $\begin{array}{l}\mathrm{RMSE}=5.763 \\
R^{2}=0.9895\end{array}$ \\
\hline$W_{b}=\left(H_{0} /\left(-70.27+17.73 H_{0}\right)\right) V$ & $\begin{array}{l}\mathrm{RMSE}=0.7867 \\
R^{2}=0.9899\end{array}$ & $W_{b}=\left(H_{0} /\left(-138.3+26.86 H_{0}\right)\right) V$ & $\begin{array}{l}\mathrm{RMSE}=2.338 \\
R^{2}=0.8928\end{array}$ \\
\hline$W_{b 2-7}=\left(H_{0} /\left(145.9+13.03 H_{0}\right)\right) V$ & $\begin{array}{l}\mathrm{RMSE}=1.474 \\
R^{2}=0.9546\end{array}$ & $W_{b 2-7}=\left(d_{g} /\left(-228.8+35.77 d_{g}\right)\right) V$ & $\begin{array}{l}\mathrm{RMSE}=0.6680 \\
R^{2}=0.9810\end{array}$ \\
\hline$W_{b 0.5-2}=\left(H_{0} /\left(-170.5+35.62 H_{0}\right)\right) V$ & $\begin{array}{l}\mathrm{RMSE}=2.366 \\
R^{2}=0.6459\end{array}$ & $W_{b 0.5-2}=\left(H_{0} /\left(-380.7+62.38 H_{0}\right)\right) V$ & $\begin{array}{l}\mathrm{RMSE}=1.644 \\
R^{2}=0.6584\end{array}$ \\
\hline$\left.W_{b 0-0.5}=H_{0} /\left(-1454+268.9 H_{0}\right)\right) V$ & $\begin{array}{l}\mathrm{RMSE}=0.3471 \\
R^{2}=0.5874\end{array}$ & $W_{b 0-0.5}=\left(H_{0} /\left(-837.3+144.9 H_{0}\right)\right) V$ & $\begin{array}{l}\mathrm{RMSE}=0.4726 \\
R^{2}=0.7442\end{array}$ \\
\hline$W_{l}=\left(H_{0} /\left(-226.4+45.27 H_{0}\right)\right) V$ & $\begin{array}{l}\mathrm{RMSE}=1.404 \\
R^{2}=0.8192\end{array}$ & $W_{l}=\left(H_{0} /\left(-512.9+69.16 H_{0}\right)\right) V$ & $\begin{array}{l}\mathrm{RMSE}=1.385 \\
R^{2}=0.5350\end{array}$ \\
\hline$W_{T}=\sum W_{i}$ & $\begin{array}{l}\mathrm{RMSE}=3.830 \\
R^{2}=0.9961\end{array}$ & $W_{T}=\sum W_{i}$ & $\begin{array}{l}\mathrm{RMSE}=2.963 \\
R^{2}=0.9983\end{array}$ \\
\hline P. sylvestris & & Q. robur & \\
\hline$W_{w+b}=\left(H_{0} /\left(-13.27+3.393 H_{0}\right)\right) V$ & $\begin{array}{l}\mathrm{RMSE}=9.340 \\
R^{2}=0.9606\end{array}$ & $W_{w+b 7}=\left(d_{g} /\left(7.012+1.537 d_{g}\right)\right) V$ & $\begin{array}{l}\mathrm{RMSE}=3.041 \\
R^{2}=0.9971\end{array}$ \\
\hline$W_{b 7}=\left(d_{g} /\left(8499-195.2 d_{g}\right)\right) V$ & $\begin{array}{l}\mathrm{RMSE}=0.2886 \\
R^{2}=0.9313\end{array}$ & $W_{b}=\left(d_{g} /\left(-27.33+11.03 d_{g}\right)\right) V$ & $\begin{array}{l}\mathrm{RMSE}=0.4882 \\
R^{2}=0.9965\end{array}$ \\
\hline$W_{b 2-7}=\left(H_{0} /\left(-133.8+26.00 H_{0}\right)\right) V$ & $\begin{array}{l}\mathrm{RMSE}=1.646 \\
R^{2}=0.9197\end{array}$ & $W_{b 2-7}=\left(d_{g} /\left(10.68+4.041 d_{g}\right)\right) V$ & $\begin{array}{l}\mathrm{RMSE}=1.306 \\
R^{2}=0.9966\end{array}$ \\
\hline$W_{b 0-2}=\left(H_{0} /\left(-146.7+26.72 H_{0}\right)\right) V$ & $\begin{array}{l}\mathrm{RMSE}=2.828 \\
R^{2}=0.6374\end{array}$ & $W_{b 0.5-2}=\left(H_{0} /\left(-476.5+58.11 H_{0}\right)\right) V$ & $\begin{array}{l}\mathrm{RMSE}=0.8611 \\
R^{2}=0.7786\end{array}$ \\
\hline & & $W_{b 0-0.5}=\left(H_{0} /\left(-1245+148.5 H_{0}\right)\right) V$ & $\begin{array}{l}\mathrm{RMSE}=0.3432 \\
R^{2}=0.5725\end{array}$ \\
\hline$W_{l}=\left(H_{0} /\left(-194.3+35.39 H_{0}\right)\right) V$ & $\begin{array}{l}\mathrm{RMSE}=2.135 \\
R^{2}=0.6372\end{array}$ & $W_{l}=\left(H_{0} /\left(-479.4+66.52 H_{0}\right)\right) V$ & $\begin{array}{l}\mathrm{RMSE}=0.9526 \\
R^{2}=0.8529\end{array}$ \\
\hline$W_{T}=\sum W_{i}$ & $\begin{array}{l}\mathrm{RMSE}=11.91 \\
R^{2}=0.9621\end{array}$ & $W_{T}=\sum W_{i}$ & $\begin{array}{l}\mathrm{RMSE}=5.443 \\
R^{2}=0.9964\end{array}$ \\
\hline
\end{tabular}

See Table 1 for an explanation of the biomass components and stand variables. RMSE values in $\mathrm{Mg} \mathrm{ha}^{-1}$ 
Table 4 Comparison of prediction accuracy in estimating biomass components and total stand biomass yielded by the two types of SBE developed

\begin{tabular}{|c|c|c|c|c|c|}
\hline \multirow[t]{2}{*}{ Species } & \multirow[t]{2}{*}{ Biomass component } & \multicolumn{2}{|c|}{$\begin{array}{l}\text { SBE including observed } \\
\text { variables }\end{array}$} & \multicolumn{2}{|c|}{$\begin{array}{l}\text { SBE including } \mathrm{BEF}_{i} \text { and stand } \\
\text { volume }\end{array}$} \\
\hline & & $F$ value & $\operatorname{Pr}>F$ & $F$ value & $\operatorname{Pr}>F$ \\
\hline \multirow[t]{7}{*}{ B. pubescens } & $W_{w+b 7}$ & 0.550 & 0.576 & 0.03 & 0.9713 \\
\hline & $W_{b}$ & 2.66 & 0.0729 & 20.01 & $<0.0001$ \\
\hline & $W_{b 2-7}$ & 2.15 & 0.119 & 21.92 & $<0.0001$ \\
\hline & $W_{b 0.5-2}$ & 16.3 & $<0.0001$ & 3.56 & 0.0304 \\
\hline & $W_{b 0.5}$ & 0.120 & 0.890 & 36.60 & $<0.0001$ \\
\hline & $W_{l}$ & 2.03 & 0.134 & 69.64 & $<0.0001$ \\
\hline & $W_{T}$ & 0.290 & 0.746 & 10.20 & $<0.0001$ \\
\hline \multirow[t]{6}{*}{ E. globulus } & $W_{w+b 7}$ & 34.0 & $<0.0001$ & 21.81 & $<0.0001$ \\
\hline & $W_{b}$ & 7.66 & 0.0005 & 5.36 & 0.0048 \\
\hline & $W_{b 0.5-7}$ & 7.58 & 0.0005 & 0.01 & 0.9919 \\
\hline & $W_{b 0.5}$ & 2037 & $<0.0001$ & 278.96 & $<0.0001$ \\
\hline & $W_{l}$ & 10.9 & $<0.0001$ & 240.99 & $<0.0001$ \\
\hline & $W_{T}$ & 24.7 & $<0.0001$ & 2.71 & 0.0670 \\
\hline \multirow[t]{7}{*}{ P. pinaster } & $W_{w+b 7}$ & 2.86 & 0.0580 & 87.39 & $<0.0001$ \\
\hline & $W_{b}$ & 8.71 & 0.0002 & 11.15 & $<0.0001$ \\
\hline & $W_{b 2-7}$ & 13.3 & $<0.0001$ & 69.02 & $<0.0001$ \\
\hline & $W_{b 0.5-2}$ & 21.8 & $<0.0001$ & 453.20 & $<0.0001$ \\
\hline & $W_{b 0.5}$ & 115 & $<0.0001$ & 95.95 & $<0.0001$ \\
\hline & $W_{l}$ & 153 & $<0.0001$ & 12.74 & $<0.0001$ \\
\hline & $W_{T}$ & 29.4 & $<0.0001$ & 48.40 & $<0.0001$ \\
\hline \multirow[t]{7}{*}{ P. radiata } & $W_{w+b 7}$ & 4.37 & 0.0132 & 4.07 & 0.0178 \\
\hline & $W_{b}$ & 7.64 & 0.0005 & 11.72 & $<0.0001$ \\
\hline & $W_{b 2-7}$ & 6.58 & 0.0015 & 13.51 & $<0.0001$ \\
\hline & $W_{b 0.5-2}$ & 9.79 & $<0.0001$ & 165.31 & $<0.0001$ \\
\hline & $W_{b 0.5}$ & 9.4 & $<0.0001$ & 348.89 & $<0.0001$ \\
\hline & $W_{l}$ & 330 & $<0.0001$ & 316.47 & $<0.0001$ \\
\hline & $W_{T}$ & 6.87 & 0.0012 & 89.24 & $<0.0001$ \\
\hline \multirow[t]{6}{*}{ P. sylvestris } & $W_{b 7}$ & 15.9 & $<0.0001$ & 0.66 & 0.5190 \\
\hline & $W_{w b}$ & 0.200 & 0.815 & 27.19 & $<0.0001$ \\
\hline & $W_{b 2-7}$ & 0.110 & 0.898 & 5.04 & 0.0072 \\
\hline & $W_{b 0-2}$ & 7.75 & 0.0006 & 47.09 & $<0.0001$ \\
\hline & $W_{l}$ & 112 & $<0.0001$ & 47.04 & $<0.0001$ \\
\hline & $W_{T}$ & 0.180 & 0.837 & 3.54 & 0.0307 \\
\hline \multirow[t]{7}{*}{ Q. robur } & $W_{w+b 7}$ & 0.090 & 0.912 & 0.10 & 0.9012 \\
\hline & $W_{b}$ & 0.080 & 0.922 & 0.32 & 0.7286 \\
\hline & $W_{b 2-7}$ & 0.070 & 0.930 & 0.55 & 0.5769 \\
\hline & $W_{b 0.5-2}$ & 0.120 & 0.888 & 66.76 & $<0.0001$ \\
\hline & $W_{b 0.5}$ & 0.180 & 0.838 & 75.76 & $<0.0001$ \\
\hline & $W_{l}$ & 0.010 & 0.990 & 49.81 & $<0.0001$ \\
\hline & $W_{T}$ & 0.050 & 0.951 & 1.15 & 0.3197 \\
\hline
\end{tabular}

SBE including $\mathrm{BEF}_{i}$ and stand volume

\begin{tabular}{|c|c|c|c|c|c|}
\hline \multirow[t]{2}{*}{ Species } & \multirow[t]{2}{*}{ Biomass component } & \multicolumn{2}{|c|}{$\begin{array}{l}\text { SBE including observed } \\
\text { variables }\end{array}$} & \multicolumn{2}{|c|}{$\begin{array}{l}\text { SBE including } \mathrm{BEF}_{i} \text { and stand } \\
\text { volume }\end{array}$} \\
\hline & & $F$ value & $\operatorname{Pr}>F$ & $F$ value & $\operatorname{Pr}>F$ \\
\hline \multirow[t]{7}{*}{ B. pubescens } & $W_{w+b 7}$ & 0.550 & 0.576 & 0.03 & 0.9713 \\
\hline & $W_{b}$ & 2.66 & 0.0729 & 20.01 & $<0.0001$ \\
\hline & $W_{b 2-7}$ & 2.15 & 0.119 & 21.92 & $<0.0001$ \\
\hline & $W_{b 0.5-2}$ & 16.3 & $<0.0001$ & 3.56 & 0.0304 \\
\hline & $W_{b 0.5}$ & 0.120 & 0.890 & 36.60 & $<0.0001$ \\
\hline & $W_{l}$ & 2.03 & 0.134 & 69.64 & $<0.0001$ \\
\hline & $W_{T}$ & 0.290 & 0.746 & 10.20 & $<0.0001$ \\
\hline \multirow[t]{6}{*}{ E. globulus } & $W_{w+b 7}$ & 34.0 & $<0.0001$ & 21.81 & $<0.0001$ \\
\hline & $W_{b}$ & 7.66 & 0.0005 & 5.36 & 0.0048 \\
\hline & $W_{b 0.5-7}$ & 7.58 & 0.0005 & 0.01 & 0.9919 \\
\hline & $W_{b 0.5}$ & 2037 & $<0.0001$ & 278.96 & $<0.0001$ \\
\hline & $W_{l}$ & 10.9 & $<0.0001$ & 240.99 & $<0.0001$ \\
\hline & $W_{T}$ & 24.7 & $<0.0001$ & 2.71 & 0.0670 \\
\hline \multirow[t]{7}{*}{ P. pinaster } & $W_{w+b 7}$ & 2.86 & 0.0580 & 87.39 & $<0.0001$ \\
\hline & $W_{b}$ & 8.71 & 0.0002 & 11.15 & $<0.0001$ \\
\hline & $W_{b 2-7}$ & 13.3 & $<0.0001$ & 69.02 & $<0.0001$ \\
\hline & $W_{b 0.5-2}$ & 21.8 & $<0.0001$ & 453.20 & $<0.0001$ \\
\hline & $W_{b 0.5}$ & 115 & $<0.0001$ & 95.95 & $<0.0001$ \\
\hline & $W_{l}$ & 153 & $<0.0001$ & 12.74 & $<0.0001$ \\
\hline & $W_{T}$ & 29.4 & $<0.0001$ & 48.40 & $<0.0001$ \\
\hline \multirow[t]{7}{*}{ P. radiata } & $W_{w+b 7}$ & 4.37 & 0.0132 & 4.07 & 0.0178 \\
\hline & $W_{b}$ & 7.64 & 0.0005 & 11.72 & $<0.0001$ \\
\hline & $W_{b 2-7}$ & 6.58 & 0.0015 & 13.51 & $<0.0001$ \\
\hline & $W_{b 0.5-2}$ & 9.79 & $<0.0001$ & 165.31 & $<0.0001$ \\
\hline & $W_{b 0.5}$ & 9.4 & $<0.0001$ & 348.89 & $<0.0001$ \\
\hline & $W_{l}$ & 330 & $<0.0001$ & 316.47 & $<0.0001$ \\
\hline & $W_{T}$ & 6.87 & 0.0012 & 89.24 & $<0.0001$ \\
\hline \multirow[t]{6}{*}{ P. sylvestris } & $W_{b 7}$ & 15.9 & $<0.0001$ & 0.66 & 0.5190 \\
\hline & $W_{w b}$ & 0.200 & 0.815 & 27.19 & $<0.0001$ \\
\hline & $W_{b 2-7}$ & 0.110 & 0.898 & 5.04 & 0.0072 \\
\hline & $W_{b 0-2}$ & 7.75 & 0.0006 & 47.09 & $<0.0001$ \\
\hline & $W_{l}$ & 112 & $<0.0001$ & 47.04 & $<0.0001$ \\
\hline & $W_{T}$ & 0.180 & 0.837 & 3.54 & 0.0307 \\
\hline \multirow[t]{7}{*}{ Q. robur } & $W_{w+b 7}$ & 0.090 & 0.912 & 0.10 & 0.9012 \\
\hline & $W_{b}$ & 0.080 & 0.922 & 0.32 & 0.7286 \\
\hline & $W_{b 2-7}$ & 0.070 & 0.930 & 0.55 & 0.5769 \\
\hline & $W_{b 0.5-2}$ & 0.120 & 0.888 & 66.76 & $<0.0001$ \\
\hline & $W_{b 0.5}$ & 0.180 & 0.838 & 75.76 & $<0.0001$ \\
\hline & $W_{l}$ & 0.010 & 0.990 & 49.81 & $<0.0001$ \\
\hline & $W_{T}$ & 0.050 & 0.951 & 1.15 & 0.3197 \\
\hline
\end{tabular}

See Table 1 for an explanation of the biomass components 
stand age for stem wood, bark, and foliage biomass equations in the model specification in order to reflect agerelated changes in stem wood density and leaf area index. Specifically, the effect of stand age on some components such as stem bark or foliage is widely recognized, because both are important components at early ages, but minor components in old stands (e.g., Antonio et al. 2007; Bi et al. 2010). In addition, silvicultural practices, such as thinning, pruning, and fertilization, which may affect the accumulation and partitioning of stand biomass among components (e.g., Albaugh et al. 2009) were not explicitly considered in the models developed. This may lead to biased stand biomass estimates, at least for some years after the treatments.

As expected, $\mathrm{BEF}_{i}$ values were not constant over stand development (Fig. 2). The trends in the values of the $\mathrm{BEF}_{i}$ in relation to stand variables were similar to those observed by Soares and Tomé (2004) for E. globulus and by Faias et al. (2009) for E. globulus and P. pinaster in the nearby region of Portugal. Therefore, constant $\mathrm{BEF}_{i}$ reported at national level in Spain (Sabaté et al. 2005) provides biased estimates of stand biomass for all of the species studied, making it necessary to model $\mathrm{BEF}_{i}$ from stand variables. Dominant height and quadratic mean diameter were the variables that best described the pattern of changes in BEF, and were therefore included in the fitting process for the system of additive equations. The rectangular hyperbole (Eq. 4) used for modeling BEF changes throughout stand development was also found by Faias et al. (2009) to be the most adequate for different species and biomass components in Portugal.

Most studies that develop models to predict BEF use stand age or growing stock as independent variables (e.g., Jenkins et al. 2003; Lehtonen et al. 2004). Although these variables were not considered in the present study, the variables selected were to a certain extent surrogates for stand development.

As regards selection of the most adequate approach, the results were nonconclusive. On one hand, the SBE systems that included $\mathrm{BEF}$ and stand volume provided a precision comparable with the SBE that included observed stand variables. However, for stem wood and total biomass equations, the prediction error associated with the former was smaller. These findings may be explained by the close relationship between stand volume and stem wood stand biomass and the high proportion of stem wood stand biomass in total stand biomass (e.g., Bi et al. 2001). On the other hand, the estimates obtained by the SBE that included $\mathrm{BEF}$ and stand volume were generally more biased than those obtained from the SBE that included observed stand variables. The poorer performance of the former approach may be a result of the slight bias remaining after modeling $\mathrm{BEF}_{i}$ from stand variables.

Finally, it must be emphasized that both alternative systems of SBE eliminated the logical inconsistency between the sum of predicted values for the stand components and the prediction for total stand. In addition, since the inherent correlation among biomass components was taken into account, they were statistically more efficient (Parresol 2001).

\section{Conclusions}

Two effective stand-basis methods of biomass estimation were developed and compared: SBE including observed stand variables and SBE including BEF and stand volume. In both cases, the fitting process considered the inherent correlation between biomass components and the constraint between the sum of predicted stand biomass components and the total stand biomass.

Overall, both methods performed similarly in estimating component aboveground stand biomass for all species studied. However, for stem wood biomass and total aboveground biomass, the use of SBE including BEF and stand volume provide more precise estimates. As the inventory effort is similar for both alternatives, the choice of which to use will depend on the data available and on the relative importance of the biomass components for the end-users.

The equations presented may be used to estimate total aboveground stand biomass and biomass of stand components for the major tree species in NW Spain, providing alternative and additional methods to the currently used scaling-up approach when treewise data are not available, as commonly occurs in strategic forest planning.

Acknowledgment Funding for this research was provided by the Spanish Ministry of Science and Education, project No AGL200766739-C02-01/FOR, and by the Spanish Ministry of Science and Innovation, project No AGL2008-02259/FOR. Part of this research was developed during a research stay at the University of León, funded by the Galician Government and cofounded with FSE founds.

\section{References}

Albaugh TJ, Bergh J, Lundmark T, Nilsson U, Luiz Stape J, Allen HE, Linder S (2009) Do biological expansion factors adequately estimate stand-scale aboveground component biomass for Norway spruce? For Ecol Manage 258:2628-2637

Antonio N, Tomé M, Tomé J, Soares P, Fontes L (2007) Effect of tree, stand, and site variables on the allometry of E. globulus tree biomass. Can J For Res 37:895-906

Balboa-Murias M, Rodríguez Soalleiro R, Merino A, Álvarez González JG (2006) Temporal variations and distribution of carbon stocks in aboveground biomass of radiata pine and maritime pine pure stands under different silvicultural alternatives. For Ecol Manage 237:29-38

Bi H, Birk E, Turner J, Lambert M, Jurskis V (2001) Converting stem volume to biomass with additivity, bias corrections and confidence bands for two Australian tree species. N Z J For Sci 31:298-319

Bi H, Turner J, Lambert M (2004) Additive biomass equations for native eucalypt forest trees of temperate Australia. Trees 18:467479 
Bi H, Long Y, Turner J, Lei Y, Snowdon P, Li Y, Harper R, Zerihun A, Ximenes F (2010) Additive prediction of aboveground biomass for P. radiata (D. Don) plantations. For Ecol Manage 12:23012314

Brooks JR, Wiant HV (2004) A simple technique for estimating cubic volume yields. For Ecol Manage 203:373-380

Chave J, Condit R, Aguilar S, Hernandez A, Lao S, Perez R (2004) Error propagation and scaling for tropical forest biomass estimates. Phil Trans R Soc Lond 359:409-420

Crecente-Campo F, Tomé M, Soares P, Diéguez-Aranda U (2010) A generalized nonlinear mixed-effects height-diameter model for E. globulus L. in northwestern Spain. For Ecol Manage 259:943952

Diéguez-Aranda U, Rojo Alboreca A, Castedo-Dorado F, Álvarez González JG, Barrio-Anta M, Crecente-Campo F, González González JM, Pérez-Cruzado C, Rodríguez Soalleiro R, López-Sánchez CA, Balboa-Murias MA, Gorgoso Varela JJ, Sánchez Rodríguez F (2009) Herramientas selvícolas para la gestión forestal sostenible en Galicia. Dirección Xeral de Montes, Consellaría do Medio Rural, Xunta de Galicia, Santiago de Compostela. http://www.usc.es/uxfs/Libros,44. Accessed 20 Oct 2011

Faias SP, Paulo J, Soares P, Patrício MS, Freire JP, Tomé M (2009) Modelling biomass expansion factors for the most important forest tree species in Portugal. Dissertation, pp. 18-38, Universidade Técnica de Lisboa

Gómez-García E (2011) Modelos dinámicos de crecimiento para rodales regulares de B. pubescens Ehrh. y Q. robur L. en Galicia. $\mathrm{Ph} . \mathrm{D}$. Thesis, Universidade de Santiago de Compostela

Greene WH (1999) Econometric analysis, 4th edn. Prentice Hall, Upper Saddle River

Husch B, Beers TW, Kershaw JA (2003) Forest mensuration, 4th edn. Wiley, New York

IPCC (2003) Good practice guidance for land use, land-use change and forestry. Institute for Global Environmental Strategies (IGES), Hayama

IPCC (2006) IPCC Guidelines for National Greenhouse Gas Inventories. Prepared by the National Greenhouse Gas Inventories Programme. In: Eggleston HS, Buendia L, Miwa K, Ngara T, Tanabe K (eds) IGES, Japan. http://www.ipcc-nggip.iges.or.jp/ public/2006gl/index.html. Accessed 29 Feb 2011

Jalkanen A, Mäkipää R, Ståhl G, Lehtonen A, Petersson H (2005) Estimation of the biomass stock of trees in Sweden: comparison of biomass equations and age-dependent biomass expansion factors. Ann For Sci 62:84-851

Jenkins JC, Chojnacky DC, Heath LS, Birdseyn R (2003) Nationalscale biomass estimators for United States tree species. For Sci 49:12-35

Kozak A, Kozak R (2003) Does cross validation provide additional information in the evaluation of regression models? Can J For Res 33:976-987

Lehtonen A, Mäkipää R, Heikkinenb J, Sievänena R, Liskic J (2004) Biomass expansion factors (BEFs) for Scots pine, Norway spruce and birch according to stand age for boreal forests. For Ecol Manage 188:211-224
Levy E, Hale SE, Nicoll BC (2004) Biomass expansion factors and root: shoot ratios for coniferous tree species in Great Britain. Forestry 77:421-430

Madgwick HAI, Oliver GR (1985) Dry matter content and production of close-spaced $P$. radiata. N Z J For Sci 15:135-141

Monserud RA, Onuchin AA, Tchebakova NM (1996) Needle, crown, stem, and root phytomass of $P$. sylvestris stands in Russia. For Ecol Manage 82:59-67

Montero G, Ruiz-Peinado R, Muñoz M (2005) Producción de biomasa y fijación de $\mathrm{CO} 2$ por los bosques españoles. Monografías INIA: Forestales $n^{\circ} 13$, Madrid

Myers RH (1990) Classical and modern regression with applications, 2nd edn. PWS-Kent, Boston

Parresol BR (1999) Assessing tree and stand biomass: a review with examples and critical comparisons. For Sci 45:573-593

Parresol BR (2001) Additivity of nonlinear biomass equations. Can J For Res 31:865-878

Sabaté S, Gracia C, Vayreda J, Ibáñez J (2005) Differences among species in aboveground biomass expansion factors in Mediterranean forests. In: Mäkipää R, et al. (eds). Effective exploitation of existing information related to BEF ensured and gaps of knowledge on BEFs of different tree species by regions identified and reported. CarboInvent. Final report for Deliverable 2.2. Document No. WP2-D2.2-Metla

SAS Institute Inc (2008) SAS/ETS ${ }^{\circledR} 9.2$ User's Guide. SAS Institute Inc, Cary

Shaiek O, Loustau D, Trichet P, Meredieu C, Bachtobji B, Garchi S, Hédi EL, Aouni M (2011) Generalized biomass equations for the main aboveground biomass components of maritime pine across contrasting environments. Ann For Sci 68:443-452

Snowdon P (1992) Ratio methods for estimating forest biomass. N Z J For Sci 22:54-62

Soares P, Tomé M (2004) Analysis of the effectiveness of biomass expansion factors to estimate stand biomass. In: Hasenauer $\mathrm{H}$, Makela A (eds.) Modeling forest production. Proceedings of the International Conference, Vienna, pp 368-374

Somogyi Z, Cienciala E, Mäkipää R, Muukkonen P, Lehtonen A, Weiss P (2007) Indirect methods of large-scale forest biomass estimation. Eur J For Res 126:197-207

UN-ECE/FAO (2000) Forest resources of Europe, CIS, North America, Australia, Japan and New Zealand (industrialized temperate/boreal countries), UN-ECE/FAO Contribution to the Global Forest Resources Assessment 2000, Main Report United Nations, New York

Vanclay JK, Skovsgaard JP (1997) Evaluating forest growth models. Ecol Model 98:1-12

Wang J, Zhang C, Xia F, Zhao X, Wu L, Kv G (2011) Biomass structure and allometry of Abies nephrolepis (Maxim) in Northeast China. Silva Fenn 45:211-226

Wirth C, Schumacher J, Schulze ED (2004) Generic biomass functions for Norway spruce in central - a meta-analysis approach toward prediction and uncertainty estimation. Tree Physiol 24:121-139

Yang Y, Monserud RA, Huang S (2004) An evaluation of diagnostic tests and their roles in validating forest biometric models. Can J For Res 34:619-629 